\title{
THE DETERMINATION OF ALBUMIN IN HUMAN BLOOD PLASMA AND SERUM. A METHOD BASED ON THE INTERACTION OF ALBUMIN WITH AN ANIONIC DYE-2-(4'-HYDROXY- BENZENEAZO) BENZOIC ACID 1, 2
}

\author{
By DAVID D. RUTSTEIN, ESTELLE F. INGENITO, AND WILLIAM E. \\ REYNOLDS WTTH THE TECH NICAL ASSISTANCE OF JEANNE M. BURKE
}
(From the Department of Preventive Medicine, Harvard University Medical School, Boston, Mass.)

(Submitted for publication August 31, 1953; accepted October 7, 1953)

Four categories of methods are presently used for the quantitative determination of the albumin content of serum or plasma in human blood. These are: (a) Electrophoresis; (b) immunological precipitation with a specific antiserum; (c) spectrophotometric measurement of the color reaction between albumin and hematin; and (d) fractional precipitation with salts or alcohol-buffer mixtures, followed by digestion and chemical colorimetry.

The electrophoretic technique of Tiselius has contributed much to knowledge of plasma albumin in biologic systems and is fully discussed in recent review articles by Stern and Reiner (1), Luetscher (2) and Gutman (3). However, electrophoresis has the disadvantages of being cumbersome and slow, requiring relatively large samples, expensive equipment, and highly skilled technicians. It is not used for routine clinical analysis.

Immunological methods modified from those proposed by Goettsch and Kendall (4), employing specific horse (5) or rabbit (6) antisera, have been recommended for the precise quantitative measurement of human serum albumin. The preparation and absorption of specific antisera of high titer is difficult. In this laboratory, immunological methods have been exacting and have failed to yield consistent results from day to day.

1 This study was supported in part by grants from the Lederle Laboratories Division, American Cyanamid Company, and the Proctor Fund, Harvard University Medical School.

2. We are grateful to Dr. Fred Karush of the Children's Hospital of Philadelphia, to Dr. Arnold M. Seligman of the Department of Surgery, Harvard University Medical School at the Beth Israel Hospital, Boston, and to Monomer-Polymer, Inc., Leominster, Massachusetts, for providing us with supplies of this dye. The dye is now commercially available from the Dajac Laboratories Division of Monomer-Polymer, Inc., Leominster, Massachusetts.
The hematin method (7) has certain limitations which tend to make it unsatisfactory for general laboratory use. The range of concentration is small and the slope of the calibration curve is such that a relatively large increment in protein concentration is necessary for a measurable change in optical density. The authors (7) stated: "Because of the narrow spectral band width involved in the determination, the photometric measuring instrument must have better resolution than the usual photoelectric colorimeter." They also pointed out, "The possibility of accessory binding by alpha globulin must be borne in mind."

The usual clinical laboratory methods for the determination of albumin in serum or plasma depend upon preliminary protein fractionation of the serum, using 21.5 per cent sodium sulfate in the Howe method (8) and 23 per cent sodium sulfate in the Kingsley modification of the Howe method (9), followed by digestion and chemical colorimetry. These salting out methods are not accurate, since they have been shown to give chemical values for albumin 10 per cent to 15 per cent higher than corresponding electrophoretic measurements (10), probably because some of the alpha globulins remain in solution (11-13). The more recent low temperature methods employing methanol-water mixtures with acetate buffers (14) or ethanol-water mixtures (13) are impractical for general clinical use.

Serum albumin differs from the other plasma proteins in its unusual affinity for numerous organic and inorganic dyes and other substances (15-21). One such substance is 2-(4'-hydroxybenzeneazo) benzoic acid,

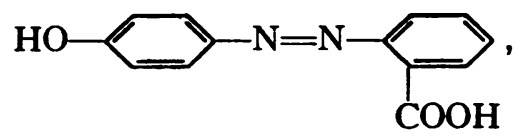


hereinafter referred to as HBABA. The use of HBABA for the measurement of albumin was first suggested by Karush (22), following his observation of the spectrophotometric absorption curves of solutions of free dye and of dye plus known concentrations of bovine albumin. Karush noted that this dye has an absorption maximum at 348 $\mathrm{m} \mu$ (except in an alkaline medium) and that there is a change in the curve in the region of $470 \mathrm{~m} \mu$ when this dye combines with bovine albumin. His observations on bovine albumin stimulated our investigations into the use of this dye for the measurement of human serum and plasma albumin.

\section{SOLUTIONS}

The solutions used in these studies are prepared as follows :

1. Stock dye solution of HBABA $\left(1 \times 10^{-8} \mathrm{M}\right)$ : dissolve $0.120 \mathrm{Gm}$. of the dye in $500 \mathrm{ml}$. of $0.01 \mathrm{M} \mathrm{NaOH}$. The $\mathrm{pH}$ of this solution varies between 11.5 and 11.7.

2. Working dye solution $\left(1 \times 10^{-4} \mathrm{M}\right)$ : add to $100 \mathrm{ml}$. of the stock dye solution enough acetate buffer at $\mathrm{pH} 5$ (23) to give a final $\mathrm{pH}$ of 6.2. (This usually requires about $14 \mathrm{ml}$.) The buffered dye is then diluted with distilled water up to $1,000 \mathrm{ml}$. in a volumetric flask to a final concentration of $1 \times 10^{-4} \mathrm{M}$.

3. Acetate buffer $(0.2 \mathrm{M})$ at $\mathrm{pH} 6.2(23)$.

4. Saline diluent: 0.1 per cent sodium chloride in distilled water.

5. Human albumin solutions $(0.20$ per cent -0.255 per cent): dilute a stock human albumin solution ${ }^{3}$ with distilled water.

\section{VALIDATION OF THE METHOD}

The use of HBABA for the precise measurement of serum and plasma albumin is validated through the following experiments :

I. Spectrophotometric absorption curve of the free dye, HBABA.

II. Comparison of the absorption curves of the free dye, HBABA, and of the dye-albumin complex.

III. Linear relationship between concentrations of albumin and the optical density of the dye-albumin solution.

IV. Non-reaction of plasma fractions other than albumin with HBABA.

3 The stock human albumin solution used in this study was supplied through the courtesy of the University. Laboratory of Physical Chemistry Related to Medicine and Public Health, Harvard University. The purity of this solution was 99 per cent, determined electrophoretically. Similar solutions are available commercially from the Cutter Laboratories, Berkeley, California.
V. Non-interference of plasma fractions other than albumin with the dye-albumin reaction.

VI. Spectrophotometric determination of albumin in normal human serum and the reproducibility of the method.

VII. Distribution of serum albumin concentrations in healthy subjects by the HBABA-spectrophotometric method.

VIII. Modification of the spectrophotometric method for use in the photoelectric colorimeter (Evelyn).

IX. Comparison of the albumin concentration in human serum by the spectrophotometric, photocolorimetric and electrophoretic methods.

$\mathrm{X}$. Comparison of the albumin concentration in abnormal serum by spectrophotometric, photocolorimetric and salting out-biuret methods.

\section{SPECTROPHOTOMETRIC ABSORPTION CURVE OF THE FREE DYE, HBABA}

Method: The optical density of solutions of the dye (HBABA) against a distilled water blank at $\mathrm{pH}$ values of $4.1,5.0,5.9,6.2,6.4$, and 7.2 were measured on the Beckman spectrophotometer 4 at various wave lengths, and a spectrophotometric absorption curve constructed. These solutions were prepared by adding to $2.5 \mathrm{ml}$. of the stock dye solution $\left(1 \times 10^{-8} \mathrm{M}\right)$ enough acetate buffer at $\mathrm{pH} 5.0$ and 6.2 to reach the desired $\mathrm{pH}$, as measured in a Beckman $\mathrm{pH}$ meter. The resulting solutions were each diluted up to $50 \mathrm{ml}$. with distilled water, and the $\mathrm{pH}$ again measured. The final concentration of the dye in the test solutions was $5 \times 10^{-5} \mathrm{M}$. This is the final concentration of the dye in all of the spectrophotometric experiments herein reported.

Results: At $\mathrm{pH}$ values of 5.0, 5.9, 6.2 and 6.4, the curves are nearly identical, the wave length of maximum absorption being $350 \mathrm{~m} \mu$ in each case (Figure 1). At the extreme $\mathrm{pH}$ levels of 4.1 and 7.2 , the wave length of maximum absorption remains at $350 \mathrm{~m} \mu$, but the curves are different. Since this experiment showed no differences in the range of hydrogen ion concentration from 5.0 to 6.4 , the convenient $\mathrm{pH}$ of 6.2 was arbitrarily selected and all subsequent experiments were performed at this hydrogen ion concentration.

Conclusion: The free dye, HBABA, in a solution of $5 \times 10^{-5} \mathrm{M}$ in acetate buffer at $\mathrm{pH}$ of 5.0 to 6.4 has a characteristic absorption curve in the spectrophotometer, with a maximum at the wave length of $350 \mathrm{~m} \mu$.

4 All the spectrophotometric readings were made in the Beckman model DU Quartz Spectrophotometer, using $10 \mathrm{~mm}$. light path corex cuvettes. Throughout the rest of this paper this apparatus will be referred to as the spectrophotometer. 
SPECTROPHOTOMETRIC ABSORPTION CURVES OF THE FREE DYE - HBABA $\left(5 \times 10^{-5} \mathrm{M}\right)$ AT VARIOUS PH LEVELS (VERSUS WATER BLANK)

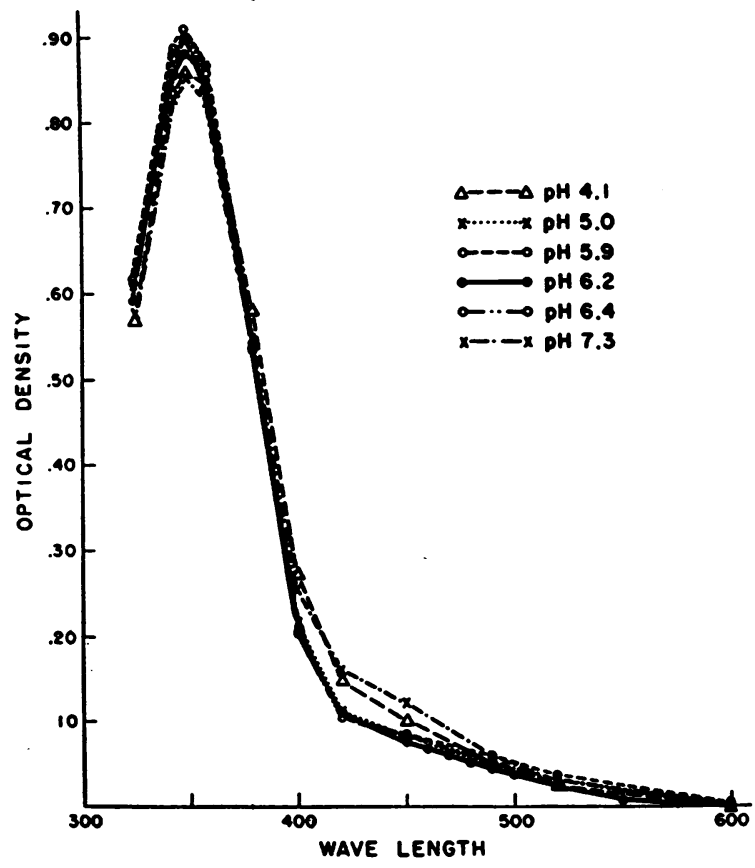

FIG. 1

II. COMPARISON OF THE ABSORPTION CURVES OF THE FREE DYE, HBABA, AND OF THE DYE-

\section{ALBUMIN COMPLEX}

Method: Two ml. of a 0.24 per cent human albumin solution were added to $12.5 \mathrm{ml}$. of the working dye solution and diluted with the saline diluent to a final volume of $25 \mathrm{ml}$. Light transmission and optical density at the wave lengths indicated in Figure 2 were measured on the spectrophotometer, using a distilled water blank in one series and a blank containing dye in the same concentration as that of the test solution ${ }^{5}$ in the second series. An absorption curve of the free dye was obtained by the method previously outlined.

Results: When read against a distilled water blank, the absorption curve of the dye-albumin complex at $\mathrm{pH} 6.2$ differs from that of the free dye in the range of $450 \mathrm{~m} \mu$ through $535 \mathrm{~m} \mu$ (Figure 2). In this range the solution containing the dye-albumin complex has a greater optical density than a solution containing the same concentration of free dye $\left(5 \times 10^{-5} \mathrm{M}\right)$. At any given wave length in this range $(450 \mathrm{~m} \mu-535 \mathrm{~m} \mu)$, the dif-

5 Hereinafter referred to as the "dye blank." ference in optical density of Curves 1 (free dye vs. $\mathrm{H}_{2} \mathrm{O}$ blank) and 2 (dye-albumin complex in an excess of dye vs. $\mathrm{H}_{2} \mathrm{O}$ blank) is equivalent to the optical density of Curve 3 (dye-albumin complex in an excess of free dye vs. the dye blank) (Figure 2).

Conclusion: The spectrophotometric absorption curve of the dye-albumin complex differs from the absorption curve of the free dye at $\mathrm{pH} 6.2$ in the range of $450 \mathrm{~m} \mu$ through $535 \mathrm{~m} \mu$, permitting the complex to be measured in the presence of an excess of free dye.

\section{LINEAR RELATIONSHIP BETWEEN CONCENTRA- TIONS OF ALBUMIN AND OPTICAL DENSITY OF DYE-ALBUMIN SOLUTION}

Method: Twelve and five-tenths $\mathrm{ml}$. of the working dye solution was pipetted into each of a series of 17 test tubes of $50 \mathrm{ml}$. capacity. Human albumin solution ( 0.2 per cent) was added in increasing amounts, followed by saline diluent up to a final volume of $25 \mathrm{ml}$. The albumin content (mg. per $25 \mathrm{ml}$.) of the 17 tubes was as follows: 0.0, 0.4, 1.0, 1.4, 2.0, 3.0, 4.0, 5.0, 6.0, 7.0, 8.0, 10.0, 12.0, 14.0, 16.0, 18.0, and 20.0. Each solution was read in the spectrophotometer at $520 \mathrm{~m} \mu$ against a water blank.

\section{SPECTROPHOTOMETRIC ABSORPTION CURVES OF THE FREE DYE - HBABA $\left(5 \times 10^{-5} \mathrm{M}\right)$ - AND OF THE DYE-ALBUMIN COMPLEX}

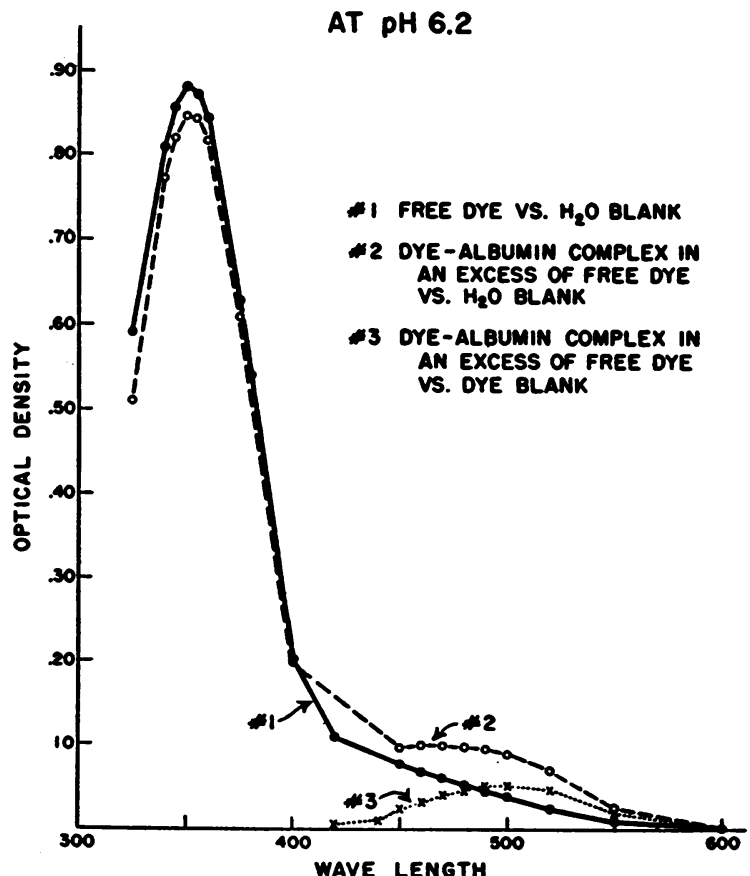

FIG. 2 


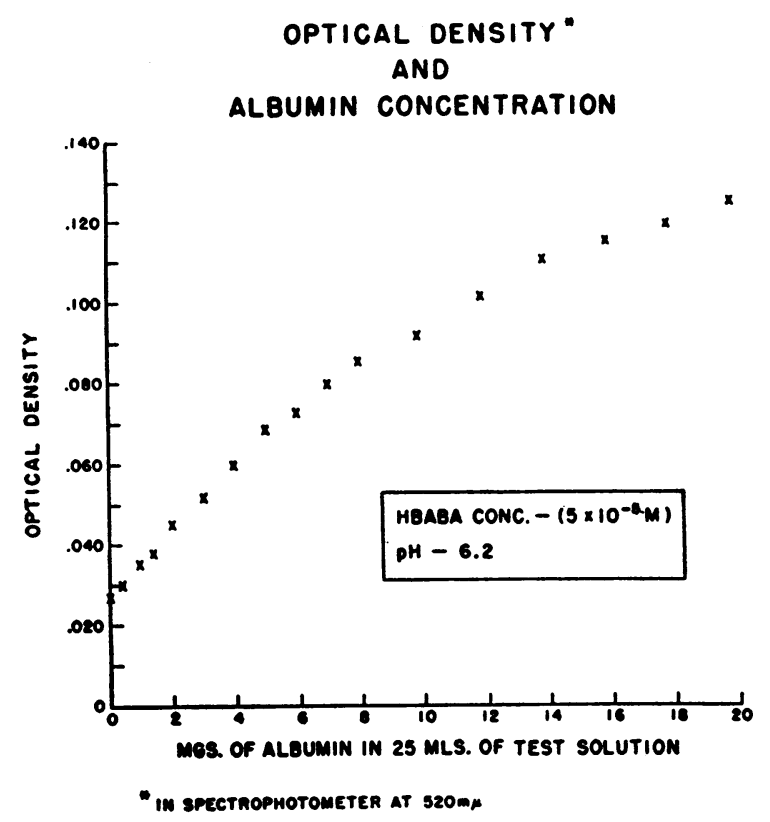

FIG. 3

Results: The optical densities of the 17 solutions of increasing albumin concentration varied from 0.027 to 0.125 (Figure 3 ). This graph indicates a linear relationship between optical density and concentration of albumin up to $6.25 \mathrm{mg}$. per $25 \mathrm{ml}$. of final test solution. This experiment was repeated with consistent results for any particular combination of standard albumin and working dye solutions. $^{6}$

Conclusion: There is a linear relationship between concentrations of albumin and optical density of dye-albumin solution in a range adequate for measurement of human serum or plasma albumin. This is the range of the "working curve" in all subsequent experiments. The stability of this curve in this range for any particular combination of standard albumin and working dye solutions permits its use, as long as the same solutions of the reagents are used and if the testing equipment is known to have stable characteristics. ${ }^{7}$

\section{NON-REACTION OF PLASMA FRACTIONS ${ }^{8}$ OTHER THAN ALBUMIN WITH HBABA}

Method: The plasma fractions tested were Fraction II -gamma globulin (13), Fraction III-lipid-bearing beta

- Mathematical analysis of these curves shows a slight deviation from true linearity, but this is of no practical significance.

7 The longest period of time during which the working curve was noted to have remained stable in the course of these experiments was five months.

8 The fraction numbers are those designated by the University Laboratory of Physical Chemistry Related to Medi-

TABLE I

Optical densities of solutions* containing $H B A B A$ plus protein fractions other than albumin

\begin{tabular}{|c|c|c|c|c|c|}
\hline \multicolumn{3}{|c|}{ Protein fractions } & \multirow[b]{2}{*}{ 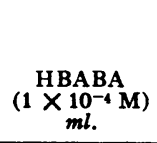 } & \multicolumn{2}{|c|}{ Optical densities* } \\
\hline $\begin{array}{l}\text { Fraction } \\
\text { number }\end{array}$ & $\begin{array}{c}\text { Amount } \\
\text { calculated } \dagger \\
\mathrm{Gm} .\end{array}$ & $\begin{array}{c}\text { Amount } \\
\text { added } \\
\mathrm{Gm} .\end{array}$ & & $\begin{array}{c}\text { Control } \\
12.5 \mathrm{ml} \text {. dye }+ \\
\text { saline to } 25 \mathrm{ml} \text {. }\end{array}$ & $\begin{array}{c}\text { Test } \\
12.5 \mathrm{ml} \text {. dye }+ \\
\text { fraction }+ \\
\text { saline to } 25 \mathrm{ml} \text {. }\end{array}$ \\
\hline II & 0.003 & 0.004 & 12.5 & $\begin{array}{l}0.026 \\
0.024\end{array}$ & $\begin{array}{l}0.027 \\
0.025\end{array}$ \\
\hline III & 0.003 & 0.004 & 12.5 & $\begin{array}{l}0.028 \\
0.027\end{array}$ & $\begin{array}{l}0.027 \\
0.027\end{array}$ \\
\hline$I I+I I I$ & 0.006 & 0.008 & 12.5 & $\begin{array}{l}0.028 \\
0.027\end{array}$ & $\begin{array}{l}0.028 \\
0.027\end{array}$ \\
\hline IV-1 & 0.0014 & 0.002 & 12.5 & $\begin{array}{l}0.027 \\
0.027\end{array}$ & $\begin{array}{l}0.025 \\
0.027\end{array}$ \\
\hline IV-7 & 0.0004 & 0.001 & 12.5 & $\begin{array}{l}0.025 \\
0.027\end{array}$ & $\begin{array}{l}0.026 \\
0.026\end{array}$ \\
\hline$I V-1+I V-7$ & 0.0018 & 0.003 & 12.5 & $\begin{array}{l}0.027 \\
0.027\end{array}$ & $\begin{array}{l}0.026 \\
0.027\end{array}$ \\
\hline$I I I+I V \ddagger$ & 0.008 & 0.008 & 12.5 & $\begin{array}{l}0.027 \\
0.027\end{array}$ & $\begin{array}{l}0.028 \\
0.026\end{array}$ \\
\hline
\end{tabular}

* Each determination was run in duplicate.

Four times the amount of protein fraction present in $0.1 \mathrm{ml}$. of normal plasma.

I Impure Fraction III (with Fraction IV). 
globulins (13), Fraction IV-alpha globulins (13), Fraction IV-1-alpha-1-lipoprotein (24), and Fraction IV-7beta metal-combining globulins (24). Each fraction was tested as indicated in Table I, being added in an amount equivalent to four times its usual concentration in $0.1 \mathrm{ml}$. of normal human plasma. In order to attain this concentration, the appropriate volume of solution containing the fraction being tested was added to $12.5 \mathrm{ml}$. of the working dye solution and diluted with saline to a final volume of $25 \mathrm{ml}$. Each solution was read in the spectrophotometer at $520 \mathrm{~m} \mu$ against a blank prepared by adding the same volume of protein fraction-containing solution diluted with saline diluent to a final volume of $25 \mathrm{ml}$. Each analysis was performed in duplicate. For comparison, a solution of the free dye was prepared by diluting $12.5 \mathrm{ml}$. of the working dye solution with saline diluent up to a final volume of $25 \mathrm{ml}$. and read in the spectrophotometer at $520 \mathrm{~m} \mu$ against a distilled water blank.

Results: The optical densities, read against a distilled water blank, of the free dye and of the free dye plus the plasma fraction, all lie within the narrow range of 0.025 to 0.027 (Table I).

Conclusion: Plasma fractions other than albumin, in four times their usual concentration in human plasma, do not change the optical density of the HBABA solution when read at a wave length of $520 \mathrm{~m} \mu$.

\section{NON-INTERFERENCE OF PLASMA FRACTIONS OTHER THAN ALBUMIN WITH THE DYE-}

\section{ALBUMIN REACTION}

Method: This experiment was performed as in Section IV, with the exception that $1.0 \mathrm{ml}$. of a 0.25 per cent human albumin solution was added to each of the test solutions, the free dye solution, and their respective blank solutions, prior to dilution with saline diluent up to $25 \mathrm{ml}$.

Results: The optical density at $520 \mathrm{~m} \mu$ of each of the test solutions, when read against its corresponding blank solution, was similar to the optical density of the solution containing only albumin and dye, when compared with its blank solution (Table II), all optical densities falling in the range of 0.045 to 0.047 .

\section{Fraction $I$}

It was not possible to perform the experiments in Sections IV and V with Fraction I (13) because of its insolubility in the dye solution. However, Fraction I goes into solution if $0.2 \mathrm{ml}$. of normal human serum is added to the dye solution before the addition of Fraction I and

cine and Public Health, Harvard University. We wish to express our thanks to that Laboratory for supplying the protein fractions used in these experiments. dilution to a final volume of $25 \mathrm{ml}$. It was therefore possible - to devise the following experiment to determine whether the optical density at $520 \mathrm{~m} \mu$, as measured by the HBABA-spectrophotometric method, of a specimen of human serum was increased by the addition of Fraction I in four times its usual concentration in human plasma.

The control solution was prepared by pipetting $0.2 \mathrm{ml}$. of human blood serum into $0.9 \mathrm{ml}$. of acetate buffer at pH 6.2 and after shaking, $12.5 \mathrm{ml}$. of working dye solution and enough saline diluent were added to bring the final volume up to $25 \mathrm{ml}$. The test solution was prepared in a similar manner, except that fibrinogen in solution was added, prior to the addition of the working dye solution and saline diluent, in an amount equivalent to four times that usually present in $0.1 \mathrm{ml}$. of normal plasma. Each of these solutions was read in the spectrophotometer at $520 \mathrm{~m} \mu$ against its corresponding blank, which contained all constituents except the dye solution. The optical densities of these two solutions were then compared, as follows :

\begin{tabular}{|c|c|c|c|c|}
\hline \multicolumn{2}{|c|}{ Fraction I } & \multirow[b]{2}{*}{$\left(\begin{array}{l}\left.\stackrel{\mathrm{HBABA}}{\times 10^{-1} \mathrm{M}}\right) \\
\mathrm{ml} .\end{array}\right.$} & \multicolumn{2}{|c|}{ Optical density } \\
\hline $\begin{array}{l}\text { Calcu- } \\
\text { lated* } \\
\mathbf{G m .}\end{array}$ & $\begin{array}{c}\text { Added } \\
\mathbf{G m} .\end{array}$ & & $\begin{array}{l}\text { Control } \\
0.9 \mathrm{ml} \text {. buffer }+ \\
0.2 \mathrm{ml} \text {. serum }+ \\
12.5 \mathrm{ml} \text {. dye }+ \\
\text { saline to } 25 \mathrm{ml} \text {. }\end{array}$ & $\begin{array}{l}\quad \text { Test } \\
0.9 \mathrm{ml} \text {. buffer }+ \\
0.2 \mathrm{ml} \text { serum }+ \\
\text { Fraction I }+ \\
12.5 \mathrm{ml} \text {. dye }+ \\
\text { saline to } 25 \mathrm{ml} \text {. }\end{array}$ \\
\hline 0.003 & 0.003 & 12.5 & 0.102 & 0.100 \\
\hline
\end{tabular}

* Four times the amount of Fraction I present in $0.1 \mathrm{ml}$. of normal plasma.

The optical density of the test solution containing buffer, serum, dye, saline diluent and Fraction $I$ is 0.100 , which is essentially the same as the optical density of 0.102 of the control solution containing all constituents of the test solution except Fraction I.

\section{Trace Components}

The fractions tested included all known serum proteins, with the exception of a few trace components in Fractions IV and V and comprising Fraction VI. The unlikely possibility still remained that if any such trace components had an unusual affinity for HBABA, interference with the dye-albumin reaction might occur. To rule this out, an experiment was performed with two lots of Stable Plasma Protein Solution, which is plasma from which a globulin fraction corresponding roughly to Fractions I, II, and III has been removed, and which contains the albumin fraction and the trace components present in Fractions IV, V, and VI. The albumin content of these two lots (determined electrophoretically by Sharp and Dohme, Inc., for the University Laboratory of Physical Chemistry Related to Medicine and Public Health, Harvard University) was 3.7 and $3.5 \mathrm{Gm}$. per cent, as compared with HBABA-spectrophotometric values in our laboratory of 3.5 and $3.3 \mathrm{Gm}$. per cent, respectively. 
TABLE II

Optical densities of solutions containing $H B A B A$ and albumin plus other protein fractions

\begin{tabular}{|c|c|c|c|c|c|c|}
\hline \multirow{2}{*}{\multicolumn{3}{|c|}{ Protein fractions }} & \multirow[b]{3}{*}{$\underset{\left(1 \times 10^{-4} \mathrm{M}\right)}{\stackrel{\text { HBABA }}{m l .}}$} & \multirow{3}{*}{$\begin{array}{c}\underset{\text { Human }}{\text { albumin }} \\
\text { solution } \\
\left(3.6 \times \mathbf{1 0}^{-5} \mathrm{M}\right) \\
\mathrm{ml} .\end{array}$} & \multicolumn{2}{|c|}{ Optical densities } \\
\hline & & & & & \multirow{2}{*}{$\begin{array}{c}\text { Control } \\
12.5 \mathrm{ml} \text { dye }+ \\
1.0 \mathrm{ml} \text {. albumin }+ \\
\text { saline to } 25 \mathrm{ml} \text {. }\end{array}$} & \multirow{2}{*}{$\begin{array}{c}\text { Test } \\
12.5 \text { ml. dye }+ \\
1.0 \text { ml. albumin }+ \\
\text { fraction }+ \\
\text { saline to } 25 \mathrm{ml} .\end{array}$} \\
\hline $\begin{array}{l}\text { Fraction } \\
\text { number }\end{array}$ & $\begin{array}{l}\text { Amount } \\
\text { calculated* } \\
\mathbf{G m} .\end{array}$ & $\begin{array}{c}\text { Amount } \\
\text { added } \\
\mathrm{Gm} .\end{array}$ & & & & \\
\hline II & 0.003 & 0.004 & 12.5 & 1.0 & 0.046 & 0.047 \\
\hline III & 0.003 & 0.004 & 12.5 & 1.0 & 0.046 & 0.047 \\
\hline$I I+I I I$ & 0.006 & 0.008 & 12.5 & 1.0 & 0.046 & 0.046 \\
\hline IV -1 & 0.0014 & 0.002 & 12.5 & 1.0 & 0.046 & 0.047 \\
\hline IV-7 & 0.0004 & 0.001 & 12.5 & 1.0 & 0.046 & 0.047 \\
\hline$I V-1+I V-7$ & 0.0018 & 0.003 & 12.5 & 1.0 & 0.046 & 0.047 \\
\hline $\mathrm{III}+\mathrm{IV}+$ & 0.008 & 0.008 & 12.5 & 1.0 & 0.045 & 0.045 \\
\hline
\end{tabular}

* Four times the amount of protein fraction present in $0.1 \mathrm{ml}$. of normal plasma.

† Impure Fraction III (with Fraction IV).

Conclusion: The presence of plasma fractions other than albumin does not interfere with the measurement of the dye-albumin complex at 520 $\mathrm{m} \mu$.

\section{SPECTROPHOTOMETRIC DETERMINATION OF AL- BUMIN IN NORMAL HUMAN SERUM AND THE REPRODUCIBILITY OF THE METHOD}

Method: This experiment was performed on serum samples obtained from 26 normal individuals, 19 males and 7 females. Specimens were all taken in the morning without regard to previous food ingestion. On any given day, the number of specimens analyzed in duplicate varied from 2 to 10 . Prior to final spectrophotometric reading, the tubes in each batch were labeled and placed in random order by someone other than the technician, so that the measurements were both "blind and ran-

\section{WORKING CURVE SPECTROPHOTOMETRIC METHOD}

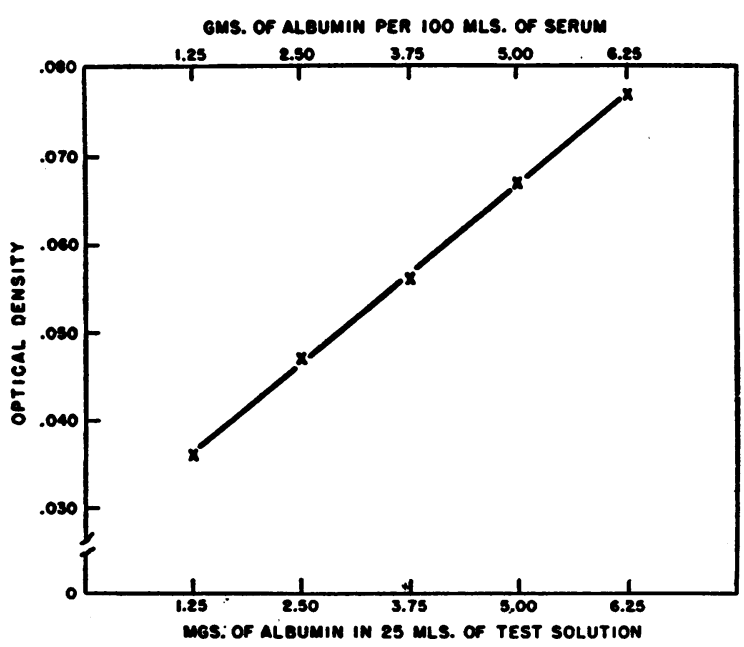

FIG. 4 dom." Measurements were performed in duplicate as follows : $0.1 \mathrm{ml}$. of serum from each specimen was added to $0.9 \mathrm{ml}$. of acetate buffer at $\mathrm{pH} 6.2$ and mixed by rotation. Twelve and five-tenths $\mathrm{ml}$. of the working dye solution was then introduced and saline diluent added to a final volume of $25 \mathrm{ml}$. Each tube was stoppered and inverted several times to assure adequate mixing. Optical density was read immediately in the spectrophotometer at $520 \mathrm{~m} \mu$ against a "serum blank," prepared by placing 0.1 $\mathrm{ml}$. of the same serum in $0.9 \mathrm{ml}$. acetate buffer at $\mathrm{pH} 6.2$ and adding saline diluent to a final volume of $25 \mathrm{ml}$. The amount of albumin present was read from the spectrophotometric working curve (Figure 4).

The spectrophotometric working curve was prepared as follows: $12.5 \mathrm{ml}$. of working dye solution was pipetted into each of five test tubes of $50 \mathrm{ml}$. capacity. Increasing amounts of a standard human albumin solution ( 0.25 per cent) were added dropwise in amounts of 0.5 , $1.0,1.5,2.0$, and $2.5 \mathrm{ml}$. The actual albumin content of each tube was, respectively, $1.25,2.5,3.75,5.0$, and $6.25 \mathrm{mg}$. albumin in $25 \mathrm{ml}$. of test solution. Saline diluent was then added to a final volume of $25 \mathrm{ml}$. in each tube. The tubes were stoppered, inverted several times and optical density was read in the spectrophotometer at $520 \mathrm{~m} \mu$ against a water blank. The optical densities were plotted against the amount of albumin in milligrams in the $25 \mathrm{ml}$. of test solution (Figure 4). This scale was specifically selected because the abscissae are numerically equivalent in the serum or plasma analyses to the number of grams of albumin per $100 \mathrm{ml}$. of serum or plasma. Thus the concentration of albumin in grams per cent of serum or plasma can be read directly from this figure.

Results: There is obviously little difference between duplicate observations on the same specimen (Table III). ${ }^{\circ}$

${ }^{9}$ For two of the samples, one of the duplicate solutions was distinctly cloudy after dilution and gave relatively high readings (Table III, No. $4-4.4$, and No. 54.9). Therefore, in the rare instance when the test solution remains cloudy after dilution, it should be discarded and the test repeated. 
Conclusion: The HBABA-spectrophotometric method for albumin determination in normal human serum is highly reproducible.

\section{DISTRIBUTION OF SERUM ALBUMIN CONCEN- TRATIONS IN HEALTHY SUBJECTS BY THE HBABA-SPECTROPHOTOMETRIC METHOD}

Method: This experiment was performed as indicated in Section VI on a series of blood specimens collected in the morning without regard to previous food ingestion, from normal individuals ( 23 males and 7 females) with an age range of 22 to 45 . This series of blood specimens includes some of those appearing in Table III, supplemented by specimens from other individuals. When duplicate measurements were made on a particular blood sample, the mean of the observations was used; where the concentration of albumin was measured in more than

TABLE III

Analyses in duplicate of normal serum albumin by $H B A B A$-spectrophotometric method

\begin{tabular}{|c|c|c|c|c|c|}
\hline $\begin{array}{c}\text { Speci- } \\
\text { men } \\
\text { number }\end{array}$ & $\begin{array}{l}\text { Albumin } \\
\text { content } \\
\text { Gm. } / 100 \mathrm{ml} . \\
\text { serum }\end{array}$ & $\begin{array}{c}\text { Differ- } \\
\text { ence }\end{array}$ & $\begin{array}{c}\text { Speci- } \\
\text { men } \\
\text { number }\end{array}$ & $\begin{array}{c}\text { Albumin } \\
\text { content } \\
\text { Gm./100 ml. } \\
\text { serum }\end{array}$ & $\begin{array}{c}\text { Differ } \\
\text { ence }\end{array}$ \\
\hline 1 & $\begin{array}{l}4.8 \\
4.6\end{array}$ & .2 & 14 & $\begin{array}{l}3.8 \\
3.8\end{array}$ & 0 \\
\hline 2 & $\begin{array}{l}4.3 \\
4.1\end{array}$ & .2 & 15 & $\begin{array}{l}4.0 \\
3.9\end{array}$ & .1 \\
\hline 3 & $\begin{array}{l}3.9 \\
3.9\end{array}$ & 0 & 16 & $\begin{array}{l}3.8 \\
3.6\end{array}$ & .2 \\
\hline 4 & $\begin{array}{l}4.4^{*} \\
3.8\end{array}$ & .6 & 17 & $\begin{array}{l}3.6 \\
3.6\end{array}$ & 0 \\
\hline 5 & $\begin{array}{l}4.9^{*} \\
4.3\end{array}$ & .6 & 18 & $\begin{array}{l}3.9 \\
3.9\end{array}$ & 0 \\
\hline 6 & $\begin{array}{l}4.4 \\
4.3\end{array}$ & .1 & 19 & $\begin{array}{l}4.6 \\
4.6\end{array}$ & 0 \\
\hline 7 & $\begin{array}{l}4.3 \\
4.0\end{array}$ & .3 & 20 & $\begin{array}{l}3.9 \\
3.8\end{array}$ & .1 \\
\hline 8 & $\begin{array}{l}4.0 \\
3.8\end{array}$ & .2 & 21 & $\begin{array}{l}5.0 \\
4.8\end{array}$ & .2 \\
\hline 9 & $\begin{array}{l}4.0 \\
4.0\end{array}$ & 0 & 22 & $\begin{array}{l}4.3 \\
4.0\end{array}$ & .3 \\
\hline 10 & $\begin{array}{l}4.3 \\
4.1\end{array}$ & .2 & 23 & $\begin{array}{l}4.2 \\
4.0\end{array}$ & .2 \\
\hline 11 & $\begin{array}{l}4.1 \\
4.1\end{array}$ & 0 & 24 & $\begin{array}{l}4.6 \\
4.4\end{array}$ & .2 \\
\hline 12 & $\begin{array}{l}4.1 \\
3.9\end{array}$ & .2 & 25 & $\begin{array}{l}4.3 \\
4.2\end{array}$ & .1 \\
\hline 13 & $\begin{array}{l}4.0 \\
4.0\end{array}$ & 0 & 26 & $\begin{array}{l}4.4 \\
4.4\end{array}$ & 0 \\
\hline
\end{tabular}

* Test solution cloudy.
MBABA-SPECTROPHOTOMETRIC MEASUREMENTS OF SERUM ALBUMIN ( 30 NORMAL SUBJECTS)

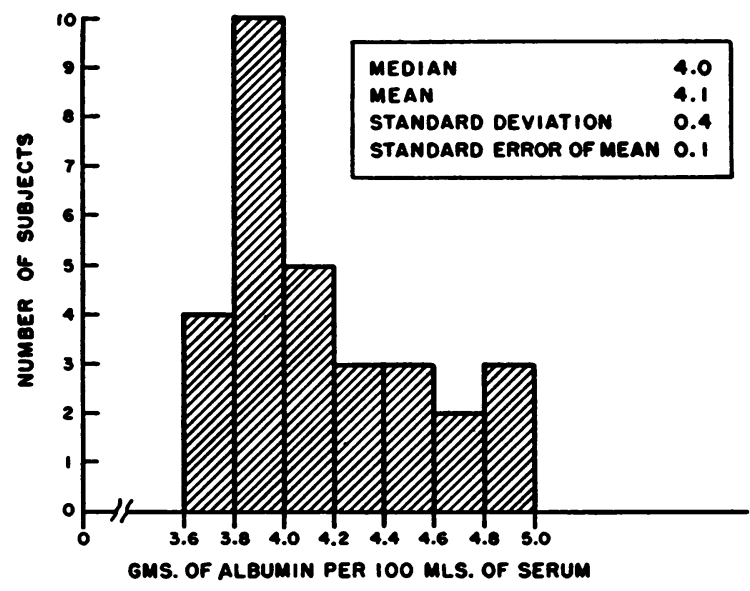

FIG. 5

one specimen from a particular individual, the result indicated in the table was selected at random.

Results: The distribution of the serum albumin measurements obtained in this total group is indicated in Figure 5. This distribution of 30 values suggests slight skewness. The median value is $4.0 \mathrm{Gm}$. per cent; the mean value is $4.1 \mathrm{Gm}$. per cent with a standard error of $\pm 0.1 \mathrm{Gm}$. per cent, and the modal class $3.8-4.0 \mathrm{Gm}$. per cent.

Conclusion: The distribution of serum albumin concentrations by the HBABA-spectrophotometric method in a small sample of normal healthy individuals is presented.

\section{MODIFICATION OF THE SPECTROPHOTOMETRIC METHOD FOR USE IN THE PHOTOELECTRIC COLORIMETER (EVELYN) 10}

The spectrophotometric method used in the first seven sections of this paper has been modified for practical use in the photoelectric colorimeter (Evelyn). Although one particular instrument was used in these experiments, the method can be similarly modified for instruments of other types. The validity of this modification is documented by comparison of the results obtained in the spectrophotometer and the photoelectric colorimeter (Section X).

10 The solutions used in the photocolorimetric and the spectrophotometric methods are the same. 
Method recommended for routine use: To a test tube containing $0.9 \mathrm{ml}$. of acetate buffer, add $0.1 \mathrm{ml}$. of fresh serum or plasma and mix well by rotation. Add 12.5 $\mathrm{ml}$. of working dye solution and saline diluent to a final volume of $15 \mathrm{ml}$. Prepare a "serum blank" (or "plasma blank") for each sample by adding $0.1 \mathrm{ml}$. of the same serum or plasma to $0.9 \mathrm{ml}$. of acetate buffer at $\mathrm{pH} 6.2$, mix well by rotation and add saline diluent to a final volume of $15 \mathrm{ml}$. The galvanometer reading for each of the test solutions is obtained in the Evelyn photoelectric colorimeter, using the " 520 " filter, after setting the galvanometer reading at 100 with the corresponding serum blank. The optical density is obtained from the conversion table and the concentration of albumin in the serum or plasma is read from the photocolorimetric calibration curve.

The calibration curve for the photoelectric colorimeter is prepared as follows: Into each of five test tubes of 25 $\mathrm{ml}$. capacity pipette $12.5 \mathrm{ml}$. of the working dye solution. Human albumin solution ( 0.25 per cent) is added dropwise in amounts of $0.5,1.0,1.5,2.0$, and $2.5 \mathrm{ml}$, respectively. The actual albumin content of each tube is, respectively, $1.25,2.5,3.75,5.0$, and $6.25 \mathrm{mg}$. of albumin in $15 \mathrm{ml}$. of test solution. Saline diluent is then added to a final volume of $15 \mathrm{ml}$. in each tube. The tubes are then stoppered and inverted several times, galvanometer readings are obtained in the photoelectric colorimeter against a water blank, using the "520" filter, and the corresponding optical densities are obtained from the conversion table. The working curve is then drawn, using the optical density as ordinate, plotted against albumin content of test solution (mg. per $15 \mathrm{ml}$.) as abscissa (Figure 6). The concentration of albumin in serum or plasma in grams per cent can be read directly from the working curve since, as in the case of the spectrophotometric working curve,

\section{WORKING CURVE PHOTOCOLORIMETRIC METHOD}

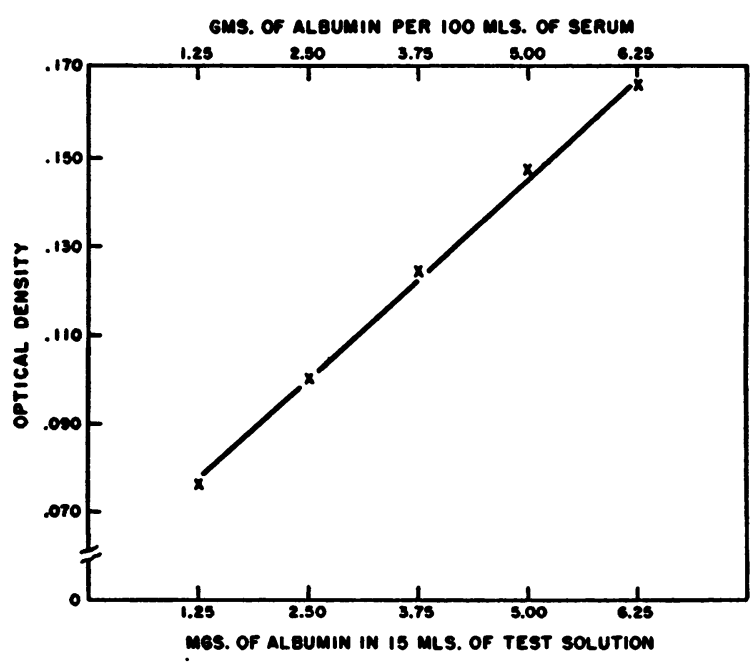

FIG. 6
TABLE IV

Comparative measurement of human serum albumin by $H B A B A$-spectrophotometric, $H B A B A$-photocolorimetric, and electrophoretic methods

\begin{tabular}{|c|c|c|c|c|}
\hline \multirow[b]{2}{*}{ Sample } & \multicolumn{2}{|c|}{$\begin{array}{l}\text { Electrophoretic } \\
\text { Gm. alb. } / 100 \mathrm{ml} .\end{array}$} & \multirow{2}{*}{$\begin{array}{c}\text { Spectro- } \\
\text { photometric } \\
\text { Gm. all./. } \\
100 \text { ml. }\end{array}$} & \multirow{2}{*}{$\begin{array}{c}\text { Photo- } \\
\text { colorimetric } \\
\text { Gm. alb. } \\
100 \mathrm{ml} .\end{array}$} \\
\hline & $6.25^{*}$ & $6.73^{*}$ & & \\
\hline $\begin{array}{c}1 \\
2 \\
3 \\
4 \dagger \\
5 \dagger \\
6 \dagger \\
7 \\
8 \\
9 \\
10 \\
11 \\
12\end{array}$ & $\begin{array}{l}3.2 \\
4.5 \\
3.8 \\
2.8 \\
2.9 \\
3.8 \\
3.5 \\
4.0 \\
4.1 \\
4.2 \\
4.1 \\
4.2\end{array}$ & $\begin{array}{l}3.5 \\
4.9 \\
4.2 \\
3.0 \\
3.2 \\
4.1 \\
3.8 \\
4.3 \\
4.4 \\
4.5 \\
4.4 \\
4.5\end{array}$ & $\begin{array}{l}4.2 \\
4.1 \\
3.9 \\
2.2 \\
2.7 \\
3.1 \\
3.7 \\
3.9 \\
3.7 \\
3.7 \\
4.2 \\
3.9\end{array}$ & $\begin{array}{l}4.2 \\
4.4 \\
4.0 \\
2.4 \\
2.9 \\
3.1 \\
4.0 \\
3.7 \\
3.6 \\
3.6 \\
3.9 \\
4.2\end{array}$ \\
\hline Mean value & 3.8 & 4.1 & 3.6 & 3.7 \\
\hline
\end{tabular}

* Conversion factor.

$\dagger$ These specimens had been diluted by previous dialysis against veronal buffer with resulting low values.

the abscissa of the photocolorimetric working curve (mg. albumin per $15 \mathrm{ml}$. of test solution) is numerically equivalent to the concentration of albumin in serum or plasma in grams per cent.

\section{COMPARISON ${ }^{11}$ OF THE ALBUMIN CONCENTRA- TION IN HUMAN SERUM BY SPECTROPHOTO- METRIC, PHOTOCOLORIMETRIC AND ELECTROPHORETIC METHODS}

Method: Twelve serum samples from normal individuals were analyzed by the spectrophotometric (Section VI), photocolorimetric (Section VIII) and electrophoretic methods. Three of these samples (Table IV-Nos. 4, 5, and 6) had been diluted by previous dialysis against veronal buffer. The spectrophotometric and photocolorimetric determinations were each performed in duplicate and the tubes and their corresponding blanks were placed in random order by someone other than the technician. The values given in Table IV for these two methods are the means of the duplicate measurements.

Electrophoresis 12 (25) was performed once on each specimen. The albumin calculations were made by multiplying the proportion of the total nitrogen concentration represented by the albumin peak (grams per cent) by the factor of 6.25 , as was done by Dole (26) and by

11 The data in this section relate only to comparative results among the three methods and do not establish "normal values" for these methods.

$12 \mathrm{We}$ are indebted for the electrophoretic measurements to Dr. J. L. Oncley, Dr. Robert Rosenberg, and Mrs. Gloria Reed of the University Laboratory of Physical Chemistry Related to Medicine and Public Health, Harvard University. 
6.73 , as has been recently recommended for the calculation of albumin (27).

Results: The spectrophotometric and photocolorimetric results on specimens of serum from 12 healthy individuals are much the same, the small differences between the means $(0.1 \pm 0.1 \mathrm{Gm}$. per cent) being insignificant $(\mathrm{P}>0.3)$. The correlation coefficient is +0.94 (95 per cent confidence limits : +0.79 to +0.98$)$.

The difference between the mean of the electrophoretic results and the average of the means of the results by the other two methods depends on whether the conversion factor of 6.25 or 6.73 is used. Using the factor of 6.25 , the mean value for albumin by the electrophoretic method is $3.8 \mathrm{Gm}$. per cent and the difference between this value and the average of the means for the other two methods $(0.1 \pm 0.1 \mathrm{Gm}$. per cent) is insignificant $(P>0.3)$. When the factor of 6.73 is used, the mean value for the electrophoretic method rises to 4.1 $\mathrm{Gm}$. per cent, the difference between it and the average of the means by the other two methods becomes $0.4 \pm 0.1 \mathrm{Gm}$. per cent, and is statistically significant $(P<0.01)$.

The correlation coefficients for the electrophoretic and each of the other two methods are independent of the conversion factors. The correlation coefficient for the electrophoretic and the spectrophotometric results is +0.71 (95 per cent confdence limits : +0.30 to +0.92 ), and that for the electrophoretic and photocolorimetric results is +0.67 (95 per cent confidence limits : +0.13 to $+0.89)$.

Conclusion: The values obtained on the samples of normal human serum by the spectrophotometric and photocolorimetric methods are in the same range. The electrophoretic values are also in the same range if a conversion factor of 6.25 is used, but are significantly higher when a factor of 6.73 is used.

\section{COM PARISON OF THE ALBUMIN CONCENTRATION}

IN ABNORMAL SERUM BY SPECTROPHOTOMETRIC, PHOTOCOLORIMETRIC AND SALTING OUTBIURET METHODS

Method: Sixteen serum samples from patients at the Massachusetts General Hospital were analyzed. The se-rum samples varied in color and clarity, and included hemolyzed, icteric, and lipemic specimens. There were all combinations of clear and turbid sera, varying in color
TABLE V

Comparative measurement of human serum albumin* by $H B A B A$-spectrophotometric, $H B A B A$-photocolorimetric and salting outbiuret methods

\begin{tabular}{cccc}
\hline \hline Sample & $\begin{array}{c}\text { Biuret } \\
\text { Gm. alb./ } \\
100 \mathrm{ml} \text {. }\end{array}$ & $\begin{array}{c}\text { Spectro- } \\
\text { photometric } \\
\text { Gm. alb. } \\
100 \mathrm{ml} .\end{array}$ & $\begin{array}{c}\text { Photo- } \\
\text { colorimetric } \\
\text { Gm. alb./ } \\
100 \mathrm{ml} \text {. }\end{array}$ \\
\hline 1 & 2.7 & 2.0 & 2.2 \\
2 & 4.9 & 3.4 & 3.2 \\
3 & 4.6 & 4.3 & 4.3 \\
4 & 4.0 & 2.8 & 2.7 \\
5 & 4.0 & 3.6 & 3.9 \\
6 & 5.0 & 4.1 & 4.1 \\
7 & 4.5 & 4.3 & 4.1 \\
8 & 4.7 & 3.9 & 3.9 \\
9 & 4.3 & 4.2 & 4.2 \\
10 & 4.6 & 4.2 & 4.5 \\
11 & 3.7 & 3.1 & 2.8 \\
12 & 3.3 & 2.7 & 3.0 \\
13 & 3.4 & 3.0 & 3.2 \\
14 & 4.0 & 3.4 & 3.6 \\
15 & 4.6 & 4.1 & 4.1 \\
16 & 4.3 & 3.5 & 4.3 \\
& & & 3.6 \\
Mean value & 4.2 & 3.5 & \\
\hline
\end{tabular}

* In specimens from 16 hospitalized patients.

from straw to red. The dilution of the serum $(1: 250$ in the spectrophotometric and $1: 150$ in the photocolorimetric methods) was adequate to clear practically all of the serum samples, including the lipemic specimens, for the purposes of the HBABA test. When an occasional lipemic specimen failed to lose its turbidity, clear serum was obtained by centrifuging at $3000 \mathrm{rpm}$. and pipetting from below the lipoid layer. The spectrophotometric and photocolorimetric determinations were performed in duplicate, and the tubes and their corresponding blanks were placed in random order by someone other than the technician. The spectrophotometric determinations were performed as in Section VI and the photocolorimetric determinations as in Section VIII. The salting out-biuret measurements were made by the routine method in use at the Massachusetts General Hospital 18 (28).

Results: The spectrophotometric and photocolorimetric results on 16 specimens of serum from hospitalized patients are much the same (Table $\mathrm{V})$, the small difference between the means $(0.1 \pm$ $0.1 \mathrm{Gm}$. per cent) being insignificant $(P>0.3)$. The correlation coefficient is +0.92 (95 per cent confidence limits : +0.79 to +0.97$)$.

In contrast, the difference between the mean of the biuret results and the average of the means of

18 The authors gratefully acknowledge the assistance of Miss G. Margaret Rourke, Research Associate, Chemistry Laboratory, Massachusetts General Hospital, and her staff, who performed the salting out-biuret analyses. 
the results by the other two methods $(0.6 \pm 0.1$ Gm. per cent) is highly significant $(\mathrm{P}<0.001)$, the results by the salting out-biuret method being higher, probably due to the presence of alpha globulin (11-13). This difference is a systematic one, since there is good correlation between the results for any particular specimen on the salting outbiuret and the spectrophotomertic and photocolorimetric methods, the correlation coefficients being, respectively, +0.85 (95 per cent confidence limits : +0.62 to +0.95$)$ and +0.75 (95 per cent confidence limits : +0.40 to +0.91$)$.

Conclusion: The values obtained on the same samples by the spectrophotometric and photocolorimetric methods are in the same range, while the biuret values are systematically higher.

\section{SUM MARY}

The selective anionic binding of an azo dye, 2(4'-hydroxybenzeneazo) benzoic acid (HBABA), to human albumin has made possible a new, reliable and relatively simple colorimetric method for measurement of serum or plasma albumin in the spectrophotometer and the photoelectric colorimeter. This method should be useful to the clinical investigator and in the hospital clinical laboratory.

\section{ACKNOWLEDGMENT}

We wish to express our appreciation to Miss Rita J. Nickerson for performing the statistical tabulations and to Miss Katharine H. Hendrie, who prepared the charts.

\section{REFERENCES}

1. Stern, K. G., and Reiner, M., Electrophoresis in medicine. Yale J. Biol. \& Med., 1946, 19, 67.

2. Luetscher, J. A., Jr., Biological and medical applications of electrophoresis. Physiol. Rev., 1947, 27, 621.

3. Gutman, A. B., The plasma proteins in disease, in Advances in Protein Chemistry, Anson, M. L., and Edsall, J. T., eds., New York, Academic Press, Inc., 1948, vol. IV, p. 155.

4. Goettsch, E., and Kendall, F. E., Analysis of albumin and globulin in biological fluids by the quantitative precipitin method. J. Biol. Chem., 1935, 109, 221.

5. Gitlin, D., Davidson, C. S., and Wetterlow, L. H., The quantitative estimation of serum albumin in human body fluids by direct titration with specific horse antiserum. J. Immunol., 1949, 63, 415.

6. Chow, B. F., Homburger, F., De Biase, S., and Petermann, M. L., A clinical method for the determina- tion of human albumin, by means of a precipitin reaction. J. Lab. \& Clin. Med., 1948, 33, 1052.

7. Rosenfeld, M., and Surgenor, D. M., The hematinbinding reaction as a basis for serum albumin determination. J. Biol. Chem., 1952, 199, 911.

8. Howe, P. E., The determination of proteins in blood -a micro method. J. Biol. Chem., 1921, 49, 109.

9. Kingsley, G. R., A rapid method for the separation of serum albumin and globulin. J. Biol. Chem., 1940, 133, 731.

10. Jager, B. V., Schwartz, T. B., Smith, E. L., Nickerson, M., and Brown, D. M., Comparative electrophoretic and chemical estimations of human serum albumin; and evaluation of six methods. J. Lab. \& Clin. Med., 1950, 35, 76.

11. Svensson, H., Fractionation of serum with ammonium sulfate and water dialysis, studied by electrophoresis. J. Biol. Chem., 1941, 139, 805.

12. Taylor, H. L., and Keys, A., Fractionation of normal serum proteins by the electrophoretic and sodium sulfate methods. J. Biol. Chem., 1943, 148, 379.

13. Cohn, E. J., Strong, L. E., Hughes, W. L., Jr., Mulford, D. J., Ashworth, J. N., Melin, M., and Taylor, H. L., Preparation and properties of serum and plasma proteins. IV. A system for the separation into fractions of the protein and lipoprotein components of biological tissues and fluids. J. Am. Chem. Soc., 1946, 68, 459.

14. Pillemer, L., and Hutchinson, M. C., The determination of the albumin and globulin contents of human serum by methanol precipitation. J. Biol. Chem., 1945, 158, 299.

15. Davis, B. D., Physiological significance of the binding of molecules by plasma proteins. Am. Scient., 1946, 34, 611.

16. Duggan, E. L., and Luck, J. M., The combination of organic anions with serum albumin. IV. Stabilization against urea denaturation. J. Biol. Chem., 1948, 172, 205.

17. Klotz, I. M., Spectrophotometric investigations of the interactions of proteins with organic ions. J. Am. Chem. Soc., 1946, 68, 2299.

18. Klotz, I. M., and Curme, H. G., The thermodynamics of metallo-protein combinations. Copper with bovine serum albumin. J. Am. Chem. Soc., 1948, 70, 939.

19. Steinhardt, J., Participation of anions in the combination of proteins with acids. Ann. New York Acad. Sc., 1941, 41, 287.

20. Teresi, J. D., The combination of organic anions with serum albumin. VII. The protein sites involved in the combination. J. Am. Chem. Soc., 1950, 72, 3972.

21. Cohn, E. J., The chemical specificity of the interaction of diverse human plasma proteins. Blood, 1948, $3,471$.

22. Karush, F., Personal communication.

23. Walpole, G. S., Notes on regulator mixtures, recent indicators, etc. II. Biochem. J., 1914, 8, 628. 
24. Surgenor, D. M., Strong, L. E., Taylor, H. L., Gordon, R. S., Jr., and Gibson, D. M., The separation of choline esterase, mucoprotein, and metal-combining protein into subfractions of human plasma. J. Am. Chem. Soc., 1949, 71, 1223.

25. Armstrong, S. H., Jr., Budka, M. J. E., and Morrison, K. C., Preparation and properties of serum and plasma proteins. XI. Quantitative interpretation of electrophoretic Schlieren diagrams of normal human plasma proteins. J. Am. Chem. Soc., 1947, 69, 416.
26. Dole, V. P., The electrophoretic patterns of normal plasma. J. Clin. Invest., 1944, 23, 708.

27. Armstrong, S. H., Jr., Budka, M. J. E., Morrison, K. C., and Hasson, M., Preparation and properties of serum and plasma proteins. XII. The refractive properties of the proteins of human plasma and certain purified fractions. J. Am. Chem. Soc., 1947, 69, 1747.

28. Gornall, A. G., Bardawill, C. J., and David, M. M., Determination of serum proteins by means of the Biuret reaction. J. Biol. Chem., 1949, 177, 751. 